\begin{tabular}{lcl}
\hline & A N N A L E S \\
UNiversitatis & MARIAE CURIE-SKŁODOWSKA \\
LUBLIN - POLONIA & 2020 \\
VOL. XXVII, 1 & SECTIOK \\
\hline
\end{tabular}

Uniwersytet Kardynała Stefana Wyszyńskiego, Instytut Edukacji Medialnej i Dziennikarstwa

\author{
RAFAŁ LEŚNICZAK
}

ORCID ID: 0000-0003-0099-4327

\title{
Idea sekularyzmu w polskiej kampanii parlamentarnej 2019 roku
}

The Idea of Secularism in the Polish Parliamentary Campaign 2019

\begin{abstract}
ABSTRAKT
Celem artykułu jest ocena stopnia obecności idei sekularyzmu w programach wyborczych głównych partii politycznych startujących w polskich wyborach parlamentarnych 2019 roku. W artykule przyjęto rozumienie tzw. sekularyzmu politycznego i odniesiono je do instytucji Kościoła rzymskokatolickiego ze względu na kontekst badań, a także na fakt, że katolicy stanowią dominującą część społeczeństwa polskiego i ze względu na doniosłe znaczenie społeczno-polityczne Kościoła katolickiego w Polsce.

Materiał badawczy stanowiły programy wyborcze partyjnych komitetów wyborczych, jak również przemówienia ich liderów politycznych wygłoszone podczas głównych wyborczych konwencji programowych.

Artykuł zwiększa wartość poznawczą zagadnienia komunikowania politycznego dotyczącego idei sekularyzmu w okresie kampanii parlamentarnej 2019 r. Badania dowiodły, że religia stała się istotnym czynnikiem dyskursu politycznego w czasie kampanii parlamentarnej w Polsce w 2019 r. Temat dotyczący roli instytucji Kościoła katolickiego w sferze publicznej był jednak podjęty jedynie przez Prawo i Sprawiedliwość oraz Lewicę. Odnotowano wyrazistą dychotomiczność poglądów tychże komitetów wyborczych. PiS wypowiedział się przeciw idei sekularyzmu, zaś Lewica tę ideę wsparła. Konfederacja, PSL oraz KW Koalicja Obywatelska przemilczały w programach wyborczych kwestię idei państwa świeckiego.
\end{abstract}

Słowa kluczowe: sekularyzm, wybory, Kościół katolicki, polityka 


\section{WSTĘP}

Relacje pomiędzy państwem a religią, miejsce religii w sferze publicznej oraz roszczenia mniejszości religijnych o uznanie są jednymi z istotnych elementów współczesnej debaty politycznej. Poliarchie zachodnie stanęły obecnie przed szeregiem wyzwań związanych z zarządzaniem różnorodnością wartości moralno-religijnych. Szeroko zakrojony pluralizm etyczny współczesnych społeczeństw wysokorozwiniętych, pogłębiająca się dywersyfikacja społeczna związana z ruchami migracyjnymi, rosnące zaangażowanie na rzecz praw człowieka, i bardziej kontrowersyjne na rzecz ,wielokulturowości”, są odpowiedzialne za ten nowy etap debaty na temat religii i polityki. Stąd też bardzo często w dyskursie publicznym powraca pytanie o rolę religii i instytucji religijnych w życiu społecznym.

Sekularyzm jest pojęciem niejednoznacznym, które otwiera możliwość odmiennych sposobów rozumienia religii w życiu publicznym ${ }^{1}$. Zostaną wskazane następujące możliwe drogi rozumienia sekularyzmu: tzw. sekularyzm polityczny, socjologiczna teoria sekularyzmu jako procesu społecznego, koncepcja sekularyzmu José Casanovy oraz koncepcja Egberta Ribberinka.

W szerokim sensie sekularyzm polityczny polega przede wszystkim na idei rozdziału Kościoła od państwa jako podstawowej zasady organizacyjnej państwa. Zasada separacji obejmuje ochronę, zarówno wolności religijnej, jak i neutralności światopoglądowej państwa. Rozdział Kościoła od państwa obejmuje: wolność religijną; równość rozumianą jako jednakowe traktowanie wszystkich religii; państwową neutralność wobec religii [Szymanek 2012: 29, 33; Węgrzecki 2018: 40-41]. Podstawową ideą tak rozumianego sekularyzmu politycznego jest to, że państwo liberalno-demokratyczne musi być świeckie, aby zapewnić równy szacunek wszystkim obywatelom niezależnie od ich światopoglądu i koncepcji dobra [Ruffini 1992: 5-15].

W ujęciu socjologicznym sekularyzm rozumiany jest jako proces społeczny. Jest on jednym z przejawów większego procesu kulturowego, który dotyczy wszystkich nowoczesnych społeczeństw: modernizacji i racjonalizacji. Procesy unowocześnienia życia społecznego obejmowały także proces sekularyzacji, systematycznie ograniczając rolę instytucji religijnych oraz religijnych przekonań i praktyk, zastępując je racjonalną organizacją opartą na rozumie i nauce. Nieuniknioną implikacją modernizacji społecznej jest zamieranie religii w sferze życia publicznego oraz w indywidualnej i zbiorowej świadomości ludzi, którą Janusz Mariański określa linearnym spadkiem religijności [Mariański 2017: 237]. Jak zauważył polski socjolog, ,według zwolenników tezy o globalnej sekularyzacji religia traktowana jako siła tradycyjna musi kapitulować w warunkach dyferencjacji społecznej, pluralizacji społeczno-kul-

1 Przez religię autor rozumie uznanie istnienia Absolutu, jak również jakąś interpretację wielkich dziedzin codziennego doświadczenia człowieka. Przyjęto, że w skład religii wchodzą następujące elementy: doktryna zawierająca twierdzenia o Bogu, kult bóstwa, zespół norm postępowania, instytucje społeczne związane z przekazywaniem doktryny, kultu i moralności [Mazanka 2014: 56; Fazio 2016]. 
turowej i strukturalnej indywidualizacji; jedna ze stron wygrywa kosztem drugiej" [Mariański 2017: 237]. Jeden z najsłynniejszych badaczy procesów kształtowania się społeczeństw nowoczesnych, Max Weber, zauważył, że w procesie tym chodziło o ustanowienie racjonalnego systemu praw i administracji we współczesnym społeczeństwie [Zaretti 2003: 25-27]. Tezę o stopniowym zaniku religijności, powiązaną z warunkami tradycyjnymi, odchodzącymi w przeszłość, niemiecki socjolog określał jako „odczarowanie świata”, które wiązało się z procesem racjonalizacji, czyli dominującej roli rozumu, nauki i argumentów „pozytywnych”, empirycznych, wobec pozbawionej takich podstaw wiary; procesem różnicowania strukturalnego i funkcjonalnego społeczeństw, prowadzącego do oddzielenia Kościoła, obrzędów i wiary od codziennego życia i zamknięcia religii w osobnej enklawie; modernizacją cywilizacyjną i zmianami struktury społecznej, wyznaczanymi przez nadejście masowej kultury, rozrywki, atrakcyjnymi formami spędzania czasu, fascynacją komercją i konsumpcją [Sztompka 2012: 372].

Pod wpływem procesów modernizacji i racjonalizacji instytucje religijne utraciły centralną rolę jako zasada organizacyjna całego społeczeństwa, zaś praktyki religijne nabrały charakteru zindywidualizowanych działań, które nie są już podstawową zasadą legitymizującą porządek społeczno-polityczny tak jak to miało miejsce w społeczeństwach preindustrialnych. Warto także zauważyć, że w niektórych niedemokratycznych systemach politycznych wprowadzono tzw. ateizm państwowy, którego celem była próba eliminacji religii z życia społecznego, ale odbywało się to w bardzo specyficznym kontekście społeczno-politycznym.

Zwolennicy tak pojętego sekularyzmu kreślą swoisty dualizm: przyjęcie tradycyjnych form religii symbolizuje „to, co przeszłe, prymitywne, nieoświecone, zabobonne i irracjonalne", natomiast porzucenie religii oznacza „wejście w stan rozumności, oświecenia, nauki i postępu" [Barnat 2017: 293-294].

Ceniony amerykański socjolog religii Peter Berger twierdził, że obok tendencji sekularyzacyjnych odnotowuje się ożywienie postaw religijnych, których motorem jest pluralizm światopoglądów i systemów wartości. „Nowoczesność (modernizacja społeczna) nie powoduje, że Bóg jest martwy (umiera), lecz że jest wielu bogów, czyli rozwijają się rozmaite nurty wiary. W warunkach upowszechniającego się pluralizmu staje się ona kwestią osobistej decyzji” [Mariański 2017: 247].

W perspektywie aksjologicznej, sekularyzm rozumie prawdziwe wartości wyłącznie jako wartości doczesne, przyczyniające się do naturalnej doskonałości człowieka. Odzwierciedla to stanowisko o czysto naturalistycznej moralności, niezależnej od religii [Tan 2017: 683].

José Casanova wyróżnia trzy znaczenia koncepcji sekularyzmu. Pierwsze z nich jest związane z najszerszym rozumieniem słowa secular i odnosi się do dychotomicznej klasyfikacji dwóch światów: religijnego-duchowego-sakralnego świata zbawienia oraz rzeczywistości świeckiej-doczesnej. W tym rozumieniu sekularyzować oznacza „czynić światowym”, przekształcać osoby lub rzeczy religijne w świeckie. Hiszpański socjolog religii rozumie to w sensie rozmywania granic między tym, co 
świeckie i tym, co religijne. W praktyce oznacza to wzajemne mieszanie się dwóch porządków: religijnego i świeckiego (mutual reciprocal infusion) [Casanova 2009: 28]. Z kolei proces emancypacji sfery świeckiej z klerykalnej kontroli kościelnej jest laicyzacją, którą naznacza antagonizm świeckie-klerykalne. Marginalizacja i prywatyzacja wszystkiego, co religijne oraz wyłączenie religijności ze sfery publicznej prowadzi do królestwa laïcité [Casanova 2009: 29]. Drugie rozumienie „sekularyzmu” w ujęciu Casanovy oznacza sytuację, gdy społeczeństwo jest „niereligijne”, tzn. pozbawione religii i jest zamknięte na jakąkolwiek formę transcendencji. Czymś typowym w społeczeństwach nowoczesnych jest akceptacja postępującego upadku przekonań i praktyk religijnych wraz z postępującym ich unowocześnieniem. A zatem według tej koncepcji, im bardziej nowoczesne społeczeństwo, tym bardziej jest ono zsekularyzowane [Casanova 2009: 29-31]. W trzecim rozumieniu sekularyzmu chodzi nie tyle o naiwne bezrefleksyjne uznanie nieobecności religii, ale o wyrazisty rezultat procesu rozwoju człowieka. Współczesna „nie-wiara” nie jest zwykłym stanem nieobecności wiary ani tylko obojętności na rzeczywistość transcendentną, ale świadomym przyjęciem koncepcji o nieracjonalności wiary [Casanova 2009: 31].

O ile tradycyjna socjologia religii była poświęcona zasadniczo badaniom procesów sekularyzacji społeczeństw przechodzących procesy modernizacyjne, to socjologowie religii młodego pokolenia wychodzą poza utarte schematy starszych kolegów. Warto zwrócić uwagę na myśl Egberta Ribberinka, który obszarem swoich badań uczynił przede wszystkim analizę upowszechniania się postaw antyreligijnych jako efektu procesów sekularyzacji. W swojej pracy doktorskiej zatytułowanej ,,There is probably no God". A quantitative study of anti-religiosity in Western Europe doszed1 do kilku ważnych, nowatorskich wniosków w kontekście badań nad polaryzacją religijną w Europie Zachodniej [Ribberink 2017]. W jego opinii, postawa antyreligijna nie jest czymś, co wiąże się z wiekiem osoby, jej niewiarą lub wykształceniem, ale to kontekst religii wywołuje tę reakcję. Antyreligijność stanowi reakcję na postawę osób deklarujących się jako wierzący, którzy niewierzących postrzegają jako niemoralnych i niebezpiecznych dla wartości narodowych. Analiza Ribberinka wskazuje rozpad instytucjonalnych „struktur wiarygodności” Kościoła jako drugą ważną przyczynę wyobcowania i anomii społeczeństw Zachodu. Wzrost sentymentu antyreligijnego w społeczeństwie odnotowuje socjolog u osób z niższym wykształceniem i demonstrowaną przez te osoby nietolerancją, np. wobec migrantów napływających z krajów muzułmańskich do Europy. Pozostawia jednak wiele pytań otwartych, wymagających dalszych badań, choćby dotyczących wpływu sentymentu nietolerancji religijnej na fluktuację religijności społeczeństwa czy też weryfikacji tego, czy w krajach bardziej zsekularyzowanych istnieje tendencja w kierunku polaryzacji świecko-religijnej, czy raczej w kierunku rosnącej tolerancji między grupami religijnymi i niereligijnymi [Ribberink 2017: 31-33]. 


\section{METODOLOGIA BADAŃ}

Na mocy postanowienia Prezydenta RP z dnia 6 sierpnia 2019 r. w sprawie zarządzenia wyborów do Sejmu i Senatu wybory parlamentarne odbyły się 13.10.2019 r. [Postanowienie Prezydenta Rzeczypospolitej Polskiej...]. Biorąc pod uwagę współczesne rozumienie kampanii wyborczej jako kampanii permanentnej, trudno precyzyjnie wskazać początkową datę rywalizacji wyborczej do polskiego parlamentu w 2019 r. [Garlicki 2010: 26-45]. Przyjęto zatem umownie następujący zakres temporalny analizy: 6.08.2019 r. - data początkowa, którą uzasadnia ww. postanowienie Prezydenta RP, zaś 12.10.2019 r. - data końcowa, związana z dniem poprzedzającym wybory i obowiązującą ciszą wyborczą.

W okresie przed 6.08.2019 r. warto wskazać kilka istotnych kwestii z agendy medialnej dotyczącej instytucji kościelnej, które zostały włączone w przedwyborczą rywalizację polityczną i które mogły wpłynąć na obecność kwestii sekularyzmu w wyborczym komunikowaniu politycznym.

Po pierwsze, wizerunek instytucji Kościoła katolickiego w Polsce przechodzi czas silnych turbulencji. Przyczyną są ujawnione w drugiej dekadzie XXI wieku skandale pedofilii niektórych duchownych, choćby casus kard. Theodore'a McCarricka, ks. Henryka Jankowskiego, abp. Juliusza Paetza [Leśniczak 2020]. Wyżej wymienione afery obyczajowe stały się powodem powstania filmów Kler w reżyserii Wojciecha Smarzowskiego [Leśniczak 2019a: 153-172] oraz Tylko nie mów nikomu autorstwa Tomasza Sekielskiego [Leśniczak 2020], których oglądalność sięgała odpowiednio: dla Kleru - ponad $5 \mathrm{mln}$ widzów w pierwszych trzech miesiącach emisji w polskich kinach [Kubica 2019] oraz dla Tylko nie mów nikomu - 23 mln wyświetleń na kanale YouTube przez pierwsze pół roku od momentu premiery [tokfm.pl 2019].

Po drugie, w czasach rządów Prawa i Sprawiedliwości (2015-2019) odnotowuje się dość wyraźny sojusz tronu i ołtarza. Instytucja eklezjalna legitymizuje działania rządzących, w zamian otrzymując przywileje prawne i ekonomiczne [Nosowski 2015: 129-139; Zuber 2017: 153-160; Leśniczak 2017: 257-277]. Aleksander Hall, w kontekście przejęcia władzy po wyborach prezydenckich i parlamentarnych w 2015 roku przez PiS, poddaje analizie sposób korzystania z tej sytuacji przez rządzących oraz stosunek Kościoła katolickiego do władzy politycznej i procesów zachodzących w Polsce [Hall 2017: 89-93]. Zdaniem polskiego historyka, biskupi i księża w okresie po 2015 roku nie ograniczyli swojej misji do poziomu metapolitycznego, ale udzielili poparcia i rekomendacji ugrupowaniu Jarosława Kaczyńskiego [Hall 2017: 90]. Jest to spowodowane kilkoma ważnymi faktami. Deklaracje PiS wyrażały ostentacyjny szacunek wobec Kościoła, wierność jego nauczaniu, stawianie znaku równości pomiędzy polską tożsamością a chrześcijaństwem. Kontekstem takiego dyskursu jest osłabienie praktyk religijnych w Polsce, dywulgacja konsumpcyjnych wzorców życia, laicyzacja kultury, a nawet, jak stwierdził Zbigniew Nosowski, agresywny antyklerykalizm z przestrzeni publicznej [Hall 2017: 91]. Po 2015 r. umocniła się znacząco w polskim Kościele pozycja toruńskiego redemptorysty Tadeusza Rydzyka, 
który w przestrzeni publicznej funkcjonuje jako biznesmen czy polityk, asocjujący zachowawczy nurt katolicyzmu z postawą obronnego patriotyzmu, a nawet nacjonalizmu [Hall 2017; Leśniczak 2019b: 279]. Kościół po przejęciu władzy przez PiS uzyskał pewność, że „w kwestiach światopoglądowych, obyczajowych, a także formalnych relacjach pomiędzy państwem a Kościołem, nie nastąpią zmiany w prawie niezgodne z jego nauczaniem [...] uznanie Kościoła musiał wzbudzić program »500+« i jego oficjalne uzasadnienie" [Hall 2017: 91], zdumiewać może jednak milczenie biskupów wobec lekceważenia konstytucji i prawa przez ugrupowanie Kaczyńskiego, czy wobec podziału wspólnoty narodowej na Polaków patriotów i Polaków „gorszego sortu” [Hall 2017: 92].

Warto również zauważyć, że istotnym czynnikiem determinującym kwestie agendy medialnej i politycznej były marsze równości celebrujące akceptację społeczną i własną przedstawicieli środowisk LGBT, w szczególności białostocki marsz z 20.07.2019 r., który spotkał się z atakiem grupy tzw. kiboli i narodowców [Skórzyński 2019].

W artykule przyjęto rozumienie tzw. sekularyzmu politycznego i odniesiono je do instytucji Kościoła rzymskokatolickiego ze względu na kontekst badań (kampania parlamentarna w Polsce w 2019 r.), a także na fakt, że katolicy stanowią dominującą część społeczeństwa polskiego i ze względu na doniosłe znaczenie społeczno-polityczne Kościoła katolickiego w Polsce [Mariański 2018: 19-36]. Dokonano również próby spojrzenia na poszczególne wyborcze programy polityczne partii w kontekście procesu emancypacji sfery świeckiej z klerykalnej kontroli kościelnej autorstwa Casanovy. Analiza ma za zadanie próbę odpowiedzi na pytanie, czy główne ugrupowania polityczne deklarowały marginalizację i prywatyzację wszystkiego, co religijne oraz wyłączenie religijności ze sfery publicznej. Istotnym pytaniem jest również to, czy i jakie stanowisko zajęły najważniejsze partie polityczne podczas kampanii parlamentarnej 2019 r. w Polsce wobec kwestii wolności religijnej, równości oraz państwowej neutralności wobec religii. Artykuł jest zatem próbą oceny stopnia obecności idei sekularyzmu w programach wyborczych głównych partii politycznych startujących w polskich wyborach parlamentarnych 2019 roku, tj.: KW Polskiego Stronnictwa Ludowego, KW Prawa i Sprawiedliwości, KW Sojuszu Lewicy Demokratycznej, KW Konfederacji Wolność i Niepodległość, Koalicyjnego KW Koalicji Obywatelskiej PO .N IPL Zieloni. Dokonano analizy polskich politycznych koncepcji dotyczących roli Kościoła w życiu publicznym. Podjęte zagadnienie dotyczy jednego z najważniejszych komponentów polskiej tożsamości narodowej, jakim jest utożsamienie przynależności do zbiorowości narodowej z wyznawaniem wiary katolickiej. Materiał badawczy stanowily programy ww. partyjnych komitetów wyborczych, jak również wypowiedzi ich liderów politycznych wyrażonych podczas krajowych wyborczych konwencji programowych. Przyjęto założenie, że programy komitetów wyborczych przygotowywane na potrzeby określonej kampanii politycznej stanowią część większej agendy programowej zapisanej w publikacjach programowych poszczególnych partii. Należy jednak podkreślić, że zakres tempo- 
ralny analizy obejmuje rok 2019, a nie szczegółową analizę historii myśli politycznej poszczególnych ugrupowań dotyczących relacji państwo-Kościół od chwili powstania danej partii politycznej. Całościowa analiza publikacji programowych poszczególnych partii wymagałaby szerszego opracowania o charakterze monografii naukowej. W badaniach wykorzystano metodę jakościowej analizy dyskursu oraz metodę analizy i syntezy.

\section{ANALIZA ZAWARTOŚCI PROGRAMÓW WYBORCZYCH PARTYJNYCH KOMITETÓW WYBORCZYCH}

Do analizy wybrano polityczne programy pięciu komitetów wyborczych ugrupowań politycznych, które zdobyły mandat w parlamencie w 2019 r. Powyższe programy znajdują się na oficjalnych witrynach internetowych ugrupowań politycznych ${ }^{2}$. W badaniach pominięto komitet wyborczy wyborców mniejszości niemieckiej, który uzyskał w Sejmie jeden mandat [Państwowa Komisja Wyborcza...].

W przeprowadzonej analizie programów dokonano próby weryfikacji obecności najważniejszych cech charakteryzujących sekularyzm oraz sposobu ich interpretowania przez poszczególne partie polityczne, tj. rozumienia prawdziwych wartości wyłącznie jako wartości doczesnych, przyczyniających się do naturalnej doskonałości człowieka (traktowanie ich jako zasad czysto naturalistycznej moralności, niezależnej od religii); wyłączenia z życia człowieka tego, co nadprzyrodzone oraz wszelkiej relacji z Bogiem; postulatu świeckich i antyreligijnych zasad jako fundamentu dla organizacji państwa.

W programie Polskiego Stronnictwa Ludowego brakuje wyraźnych odniesień do wartości chrześcijańskich, nie jest również sprecyzowane miejsce religii i instytucji Kościoła katolickiego w sferze publicznej. Autorzy programu wyborczego PSL odwołują się jednak do tradycji i myśli politycznej Witosa: „Będąc spadkobiercami 125-letniej tradycji, kierując się myślą Wincentego Witosa, jesteśmy przekonani, że Polska potrzebuje współdziałania różnych środowisk na rzecz dobrej przyszłości naszych dzieci i wnuków" [KW Polskie Stronnictwo Ludowe...].

Można zatem domniemywać, że stosunek PSL do religii jest zbieżny z poglądami Witosa. Należy zauważyć, że punkt 6 uchwalonego 10.11.1919 r. programu stronnictwa chłopskiego PSL „Piast”, zatytułowany „Państwo i Kościół” stanowił, że podstawą siły państwowej jest poczucie karności obywatelskiej. Nad jej rozwojem zaś ,,powinny czuwać u młodzieży państwo i religia wspólnymi siłami” [Żmuda 1983: 28-29]. Zjednoczenie Włościan, jedno ze stronnictw ludowych przedwojennej Polski, wchłonięte przez PSL „Piast” Wincentego Witosa, dążyło do tego, ,aby pomiędzy państwem

2 Materiał badawczy znajdował się na następujących stronach WWW komitetów wyborczych: [KW Polskie Stronnictwo Ludowe; KW Prawo i Sprawiedliwość; KW Sojusz Lewicy Demokratycznej; KW Konfederacja Wolność i Niepodległość; Koalicyjny KW Koalicja Obywatelska PO .N IPL Zieloni]. 
a poszczególnymi wyznaniami panowała zgoda, stąd rząd nie powinien ingerować w sprawy Kościoła, tak jak z drugiej strony, każde wyznanie powinno starać się z państwem współpracować. Ponieważ jednak przeważająca część narodu jest wyznania katolickiego, uważa stronnictwo religię katolicką za religię stanu" [Żmuda 1983: 29]. Na marginesie tej refleksji warto zauważyć, że drugie ze stronnictw ludowych przedwojennej Polski - PSL ,Wyzwolenie” - domagało się rozdziału państwa i Kościoła. Jego działacze zwracali uwagę na to, że duchowieństwo katolickie w Polsce w latach 1918-1939 brało bardzo czynny udział w polityce i nadużywało uczuć religijnych ludu do celów politycznych [Żmuda 1983: 30]. Stosunek stronnictw ludowych do Kościoła w czasach przed II wojną światową nie był zatem jednolity, niemniej jednak traktując myśl polityczną Witosa jako punkt odniesienia dla dzisiejszego PSL, można skonstatować, że program analizowanego komitetu wyborczego nie wspiera haseł sekularyzmu. Działacz ruchu ludowego właściwie oceniał historyczne przyczyny napięcia hierarchicznego Kościoła katolickiego z ludowcami: wielowiekowa supremacja Kościoła na wsi, nadużycia finansowe kleru, przyjmowanie przez Kościół roli obrońcy klas posiadających [Gmitruk 2016: 51]. Witos dążył do realizacji wolności religijnej, dlatego też był przeciwny, aby nadawać Polsce status państwa wyznaniowego [Gmitruk 2016: 53]. Jednocześnie należy odnotować jego inicjatywę w pracy nad konkordatem ze Stolicą Apostolską z 1925 r., co dowodziłoby jego przeciwstawieniu się postawie antyklerykalnej [Gmitruk 2016: 53-54].

Jak zauważyła Karolina Kotulewicz, „,na uwagę zasługuje wkład PSL w określeniu w konstytucji RP w 1997 r. miejsca Kościoła katolickiego oraz innych kościołów i wyznań religijnych w życiu państwa oraz zapewnienie prawa do nauczania religii w szkole i prawa rodziców do wychowywania dzieci zgodnie z własnymi przekonaniami. Przedstawiciele PSL zgłosili propozycję przepisu konstytucyjnego, na podstawie którego stosunki państwo-Kościół katolicki określa konkordat i ustawy. PSL optowało za tym, by konstytucja uwzględniała światopoglądy wierzących i niewierzących, oraz zaproponowało, żeby nie umieszczać w ustawie zasadniczej zapisów określających charakter państwa" [Kotulewicz 2014: 25]. W opracowanym projekcie konstytucji uwzględniono m.in. „uznanie naturalnych i niezbywalnych praw każdego człowieka do życia, wolności, godności i podmiotowości w życiu społecznym oraz uznanie zasad etyki chrześcijańskiej i humanizmu chrześcijańskiego jako trwałej podstawy kształtowania norm życia państwowego i międzynarodowego" [Kotulewicz 2014: 23]. Polskie Stronnictwo Ludowe opowiada się za modelem państwa świeckiego, ale nie antyreligijnego. Podkreśla doniosłość neutralności światopoglądowej instytucji państwowych, które powinny gwarantować ochronę wolności wyznaniowej oraz wspierać poszanowanie dla autonomii wspólnot religijnych i władz państwowych [Kotulewicz 2014: 26].

Program Prawa i Sprawiedliwości już w pierwszym rozdziale programu wyborczego, zatytułowanym „Wartości i zasady”, eksponuje zbieżne z Magisterium Kościoła poglądy dotyczące fundamentalnych wartości, takich jak: ochrona życia, gwarancja wolności, ludzka solidarność [KW Prawo i Sprawiedliwość: 6]. PiS deklaruje, odwo- 
łując się do tradycji greckiej i judeochrześcijańskiej, że życie ludzkie jest wartością najwyższą: „Nasz szacunek dla życia rozciąga się na całe jego trwanie. Dlatego stanowczo bronimy życia i przeciwstawiamy się każdej formie przemocy, która mu zagraża, zarówno fizycznej, jak i ideologicznej" [KW Prawo i Sprawiedliwość: 7].

Zaprezentowane $\mathrm{w}$ dokumencie rozumienie rodziny jest zbieżne $\mathrm{z}$ modelem chrześcijańskim [Niewęgłowski 2004: 399-410]: „Rodzina, opierająca się na trwałym związku kobiety i mężczyzny, jest podstawą życia społecznego. To przede wszystkim w rodzinie kształtowana jest osobowość człowieka, przekazywane są mu wartości i zaspakajane szczególnie istotne potrzeby, w tym potrzeba bliskości z innymi ludźmi, miłości. W rodzinie rodzą się dzieci, a więc jest realizowany podstawowy warunek trwania ludzkości - ciągłość pokoleń. Rodzina jest niemożliwa do zastąpienia, niezależnie od perspektywy patrzenia - religijnej lub świeckiej; w swym monogamicznym i trwałym kształcie jest podstawą naszej cywilizacji” [KW Prawo i Sprawiedliwość: 11].

Program wyborczy PiS traktował ideologię gender jako groźną dla rodziny i rodzicielstwa oraz deklarował gotowość obrony rodziny naturalnej [KW Prawo i Sprawiedliwość].

Obszerny akapit programu Prawa i Sprawiedliwości dotyczy roli religii i stosunku do Kościoła katolickiego [KW Prawo i Sprawiedliwość: 14-15]. Autorzy dokumentu eksponują wyjątkową rolę narodowotwórczą, cywilizacyjną oraz ochronną Kościoła katolickiego w Polsce: „Już w średniowieczu Kościół odparł obce próby sprawowania władzy, następnie wśród duchowieństwa wyrośli pierwsi autorzy wzywający do naprawy Rzeczypospolitej. W skrajnie niesprzyjających okolicznościach czasu zaborów, podobnie jak w PRL, Kościół był ostoją polskości, pełnił rolę zastępczą wobec nieistniejącego suwerennego państwa. W tym kontekście trzeba wspomnieć osobę i naukę Prymasa Tysiąclecia księdza kardynała Stefana Wyszyńskiego" [KW Prawo i Sprawiedliwość: 14].

Obok polskiej tradycji i polskiego patriotyzmu, nauka Kościoła katolickiego w opinii polityków PiS współbuduje tożsamość polityczną narodu [KW Prawo i Sprawiedliwość]. Jak zauważyli autorzy programu, ,zbieżność między nauką Kościoła katolickiego a tradycją narodową jest wyraźnie widoczna w odniesieniu do rodziny" [KW Prawo i Sprawiedliwość].

Dokument przypisuje także szczególną rolę Kościołowi katolickiemu w obszarze aksjologii, którego nikt nie jest w stanie zastąpić: „Kościół katolicki jest depozytariuszem i głosicielem powszechnie znanej w Polsce nauki moralnej. Nie ma ona w szerszym społecznym zakresie żadnej konkurencji, dlatego też w pełni jest uprawnione twierdzenie, że w Polsce nauce moralnej Kościoła można przeciwstawić tylko nihilizm. Znamy to z historii - próby zaszczepienia innego systemu wartości podejmowane przez zaborców lub komunistów oznaczały w efekcie zwykle odrzucenie humanistycznych wartości i zrelatywizowanie kodeksu etycznego. $Z$ tych powodów specyficzny status Kościoła katolickiego w naszym życiu narodowym i państwowym jest wyjątkowo ważny; chcemy go podtrzymać i uważamy, że próby 
niszczenia i niesprawiedliwego atakowania Kościoła są groźne dla kształtu życia społecznego" [KW Prawo i Sprawiedliwość: 15].

Program wyborczy PiS podkreślał również wzmocnienie zakazu dyskryminacji pracowników, studentów i uczniów ze względu na głoszone poglądy i wyznanie [KW Prawo i Sprawiedliwość: 206].

Z kolei postulaty Lewicy dowodzą zamiaru realizacji idei państwa świeckiego. Wskazuje na to jeden z punktów programu, zatytułowany „Świeckie państwo”, prezentujący sposób implementacji idei sekularyzmu [KW Sojusz Lewicy Demokratycznej: 15]. KW Lewicy postuluje m.in. wprowadzenie kas fiskalnych dla księży, likwidację Funduszu Kościelnego, wycofanie religii ze szkół, likwidację klauzuli sumienia: „Wprowadzimy kasy fiskalne dla księży. Sprawiedliwie opodatkujemy Kościół. Zobowiążemy kościoły do ujawniania przychodów na takich samych zasadach, jakie dotyczą organizacji pozarządowych. Docelowo zlikwidujemy przywileje podatkowe wszystkich kościołów i związków wyznaniowych. Likwidacja Funduszu Kościelnego. W 2018 roku udział państwa w Funduszu Kościelnym osiągnął rekordowy poziom $156 \mathrm{mln}$ zł. W obecnym otoczeniu gospodarczym i po zakończeniu prac Komisji Majątkowej nie ma uzasadnienia dla dalszego funkcjonowania tej instytucji. Wykreślimy tę pozycję z budżetu. [...] Wycofamy religię ze szkół, a zaoszczędzone w ten sposób pieniądze przekażemy na dodatkową naukę języka angielskiego. Zlikwidujemy klauzulę sumienia. Zapewnimy pełną dostępność usług i produktów medycznych niezależnie od przekonań lekarzy, pielęgniarek, położnych, farmaceutów. W żadnej placówce publicznej nie będzie można ograniczać usług powołując się na klauzulę sumienia, bez względu na ich rodzaj” [KW Sojusz Lewicy Demokratycznej].

Program Lewicy dowodzi zamiaru ustanowienia takich praw obywatelskich, które stoją w sprzeczności z wartościami chrześcijańskimi (np. prawo kobiet do aborcji, refundacja antykoncepcji, wprowadzenie związków partnerskich), i które wyłączają z życia to, co nadprzyrodzone oraz wszelkie relacje z Panem Bogiem: „Wprowadzimy uzależnione wyłącznie od decyzji kobiety prawo do przerwania ciąży do 12. tygodnia, a po 12. tygodniu ciąży - w przypadku zagrożenia życia lub zdrowia kobiety albo ciężkich wad płodu. [...] Zapewnimy refundację nowoczesnej antykoncepcji, w tym tabletek »dzień po«. [...] Wprowadzimy równość małżeńską i związki partnerskie dla wszystkich. Osoby wstępujące w związek partnerski w Urzędzie Stanu Cywilnego będą miały zagwarantowane prawo, między innymi, do uzyskania informacji medycznej, odwiedzin w szpitalu, dziedziczenia" [KW Sojusz Lewicy Demokratycznej: 16].

Program KW Konfederacja. Wolność i Niepodległość jest pozbawiony odniesień do idei sekularyzmu. Dokument odrzuca ideologię LGBT, postuluje prawo rodziców do wychowania dzieci w zgodzie z ich wartościami oraz prawne gwarancje bezpieczeństwa życia od poczęcia3: „Obronimy szkoły przed inwazją samozwańczych »sek-

3 Trudno określić, czy intencją tworzących program była naturalistyczna moralność niezależna od religii czy odwołanie się do moralności chrześcijańskiej. 
sedukatorów« i propagandystów ruchu LGBT. Zadbamy o należyte respektowanie prawa dzieci do poszanowania ich wrażliwości i nienarażanie na indoktrynację czy kontakt z treściami niedopasowanymi do wieku. Zagwarantujemy prawo rodziców do wychowania dzieci w zgodzie z ich wartościami. Szkoła w procesie wychowania ma wspierać rodziców, a nie z nimi rywalizować. [...] Jesteśmy zgodni, co do pilnej konieczności prawnych gwarancji bezpieczeństwa życia od poczęcia. Upomnimy się o projekty mające na celu ochronę życia nienarodzonych, które zostały zignorowane przez obecnie sprawujących władzę. Zainicjujemy kampanię informacyjną - aby każdy Polak mógł usłyszeć bicie serca dziecka słyszalne już w 6 . tygodniu życia płodowego - z jasno deklarowanym celem zapewnienia prawnej ochrony życia każdego Polaka, bez względu na wiek, stan zdrowia czy sytuację życiową" [KW Konfederacja Wolność i Niepodległość: 12].

Program wyborczy KW Koalicji Obywatelskiej nie zawierał bezpośrednich i czytelnych odniesień do idei sekularyzmu [Koalicyjny KW Koalicja Obywatelska PO .N IPL Zieloni]. Zdaniem autora, można to uzasadnić szeroką ideologicznie formułą osób tworzących porozumienie: „Powołaliśmy szeroką Koalicję Obywatelską jako porozumienie osób rozumiejących doniosłość wyzwań, które stawiają przed Polską i Polakami czasy obecne. Koalicja Obywatelska łączy osoby centrum, umiarkowanej prawicy i lewicy, które jednoczy cel, jak się zdaje, najważniejszy dziś dla przeważającej części Rodaków: Polski demokratycznej, uczciwej, bezpiecznej i osadzonej mocno w Europie" [Koalicyjny KW Koalicja Obywatelska PO .N IPL Zieloni: 3].

Wyraziste odniesienie do aksjologii chrześcijańskiej, postulatów świeckich czy antyreligijnych nie sprzyjałoby spójności koalicji, która pod względem ideologicznym stanowi niespójny konglomerat. Jak zauważył Piotr Pacewicz, Platforma Obywatelska w kampanii parlamentarnej 2019 r. unikała podjęcia narzuconego przez PiS sporu o ,katolicką Polskę” zagrożoną przez „lewactwo” [Pacewicz 2019]. W opinii publicysty Oko.press, Platforma obawiała się wystąpienia w obronie świeckiego państwa i chciała przeczekać krucjatę prawicy, która wykorzystała głośną krytykę Kościoła w wystąpieniu Leszka Jażdżewskiego z dnia 3.05.2019 r. do ataku na Donalda Tuska i całą opozycję [Pacewicz 2019]. Był to zatem celowy unik Platformy, nawet jeśli ich wyborcy „w znacznej większości [są] zwolennikami wprowadzenia w Polsce nowoczesnych regulacji prawnych, sprzecznych z nauczaniem Kościoła w dziedzinie tzw. etyki seksualnej. Są też zwolennikami ograniczenia roli Kościoła w życiu publicznym i bardzo krytycznie oceniają postawę tej instytucji w kontrolowaniu i rozliczaniu molestowania seksualnego przez księży” [Pacewicz 2019].

WYPOWIEDZI LIDERÓW POLITYCZNYCH A IDEA SEKULARYZMU

Jako najważniejsze i najbardziej reprezentatywne dla poszczególnych komitetów wyborczych, w ramach kampanii parlamentarnej 2019 r., potraktowano następujące konwencje krajowe: 
- konwencja krajowa PSL w Płocku, 17.08.2019 r. [PAP, TVN24];

- konwencja krajowa Prawa i Sprawiedliwości w Lublinie, 7.09.2019 r. [PAP, TVN24 2019];

- konwencja krajowa Lewicy na warszawskim Ursynowie, 24.08.2019 r. [PAP 2019];

- konwencja krajowa Konfederacji Wolność i Niepodległość w Warszawie, 21.09.2019 r. [Polsat News 2019];

- konwencja krajowa Koalicji Obywatelskiej w Warszawie, 6.10.2019 r. [Kolenda-Zaleska 2019].

W powyższych konwencjach uczestniczyli najważniejsi liderzy poszczególnych ugrupowań politycznych oraz zaprezentowano program wyborczy. Komunikaty polityczne poddano analizie z punktu widzenia idei sekularyzmu.

W konwencji KW Polskie Stronnictwo Ludowe odnotowano jedynie ogólne odwołania do tradycji: „Z dumą przychodzimy we wspólnocie uświęconej tradycji ruchu ludowego, reprezentowanej przez zielone historyczne sztandary. Wierni naszej tradycji. Wierni hasłu: »Żywią i Bronią. Bóg, Honor, Ojczyzna«. Idziemy dziś do kolejnych wyborów, do kolejnej bitwy o lepszą Polskę - zadeklarował [Kosiniak-Kamysz]" [PAP, TVN24]. W przemówieniu Władysława Kosiniaka-Kamysza nieobecne były kwestie dotyczące idei państwa świeckiego oraz zabrakło czytelnego odniesienia do roli Kościoła katolickiego w życiu społecznym.

Prezes PiS Jarosław Kaczyński podczas przemówienia wygłoszonego na konwencji wyborczej w Lublinie odwołał się do modelu rodziny chrześcijańskiej: „Prezes PiS mówił, że człowiek jest istotą społeczną, która żyje wśród innych i tworzy wspólnoty. Jak dodał, »dwie z nich uważamy za fundamentalne, najważniejsze. Pierwsza z nich - jak podkreślił - to rodzina. - Tak, rodzinę uważamy za komórkę społeczną o zupełnie fundamentalnym znaczeniu dla ciągłości pokoleń, dla przekazywania kultury, cywilizacji, dla trwałości większych wspólnot« - powiedział. Ale - dodał - »rodzinę widzimy tak, jak tutaj, jedna kobieta, jeden mężczyzna w stałym związku i ich dzieci«. - To jest rodzina - zaznaczył. Według niego, »rodzina tak rozumiana jest atakowana, atakowane są naturalne różnice między ludźmi, między kobietami a mężczyznami«. - Oczywiście, między kobietami, a mężczyznami - chcę to bardzo mocno podkreślić - musi być pełna równość. To mówię z całą mocą podkreślił Kaczyński” [PAP, TVN24 2019].

Lider Prawa i Sprawiedliwości wyeksponował znaczenie Kościoła katolickiego jako depozytariusza systemu wartości, istotnego czynnika w budowaniu postaw patriotycznych, jak również wskazał jego zasługi historyczne: „Kaczyński mówił również, że »chrześcijaństwo jest częścią naszej tożsamości narodowej«. - Kościół był i jest głosicielem i dzierżycielem jedynego, powszechnie znanego w Polsce systemu wartości - podkreślił. Jak mówił, »poza nim, poza może jakimiś bardzo niewielkimi partykularnie funkcjonującymi systemami, mamy tyko nihilizm«. Stwierdził, że dlatego Kościół jest ważny dla Polaków i polskich patriotów niezależnie od tego, czy ktoś jest wierzący, jest agnostykiem lub jest zupełnie niewierzący. - Każdy 
dobry Polak musi wiedzieć, jaka jest rola Kościoła, musi wiedzieć, że poza nim jest - jeszcze raz to powtarzam - nihilizm. I ten nihilizm my odrzucamy, bo nihilizm niczego nie buduje, nihilizm wszystko niszczy - powiedział Kaczyński. [...] Prezes PiS przypomniał, że w historii naszego narodu, były trudne dzieje. Zdaniem Kaczyńskiego, Kościół katolicki odgrywał wielką rolę w kształtowaniu narodu polskiego, później w jego obronie, także w tym ostatnim okresie zniewolenia, zniewolenia komunistycznego" [PAP, TVN24 2019].

Liderzy Lewicy podczas konwencji krajowej w Ursusie imputowali Kościołowi katolickiemu w Polsce, że nie rozlicza się z płacenia podatków, zgodnie z zasadą sprawiedliwości społecznej: „System podatkowy powinien odzwierciedlać zasady sprawiedliwości społecznej, nie może być od niego odstępstw i wyjątków nawet dla kleru - wskazywał. - Konstytucja jest ważniejsza od ewangelii - dodał [Włodzimierz Czarzasty]" [PAP 2019].

Robert Biedroń zadeklarował zmianę przepisów dotyczących ochrony życia nienarodzonych, legalizację związków partnerskich, zniesienie przywilejów podatkowych duchowieństwa, likwidację Funduszu Kościelnego, opodatkowanie tacy, zaprzestanie finansowania religii w szkołach: „Lider Wiosny zwrócił uwagę, że obecnie głos kobiet w Polsce jest ograniczony. - Przerwiemy piekło kobiet, o którym pisał ponad sto lat temu Tadeusz Boy-Żeleński, i w końcu, nareszcie, zagwarantujemy wszystkim kobietom prawo do bezpiecznego, legalnego przerywania ciąży na żądanie do 12 tygodnia - zapowiedział. Dodał, że Lewica zlikwiduje klauzulę sumienia, wprowadzi europejskie standardy opieki okołoporodowej i zagwarantuje Polkom dostęp do pigułki dzień po. [...] Zapowiedział także wprowadzenie związków partnerskich i ustawowej równości małżeńskiej. - Nie ma czegoś takiego jak tęczowa zaraza. Jest tylko zaraza nienawiści, która opanowała niektórych polityków i księży. Jeśli czymkolwiek jednak możemy się zarazić - to dzisiaj to pokazujemy - możemy zarażać miłością. I tym będzie zarażała Lewica. I tym powinni Polki i Polacy zarażać się nawzajem - miłością. Gdy oni chcą tworzyć strefy wykluczające innych, obiecujemy, my będziemy bronić jednej strefy - strefy wolności, która nazywa się Polska. Państwa, w którym każdy i każda będzie czuł się bezpiecznie jak u siebie w domu - zaznaczył Biedroń. Jak przekonywał, Kościół katolicki w Polsce »ma więcej ziemi niż ktokolwiek poza Skarbem Państwa, więc nie ma powodu, żeby wypłacano mu jakiekolwiek zapomogi i wsparcie«. - Ksiądz w przeciętnej parafii w Polsce płaci ok. 240 zł podatku. To jest kilkakrotnie mniej niż w tej samej parafii jego parafianin prowadzący zakład fryzjerski albo warsztat samochodowy. Koniec z przywilejami podatkowymi. Sprawiedliwie opodatkujemy Kościół, wprowadzimy w kościołach i parafiach kasy fiskalne dla księży, zlikwidujemy Fundusz Kościelny i opodatkujemy tacę. Wycofamy też nareszcie, bo zbyt długo na to czekamy, nauczanie lekcji religii ze szkół i przestaniemy je finansować - obiecywał lider Wiosny" [PAP 2019].

Podczas konwencji wyborczej KW Konfederacja został wyeksponowany sprzeciw ugrupowania politycznego wobec ideologii LGBT, choć bez odwołania do zasad moralności chrześcijańskiej: „Konfederacja chce także oddania rodzicom prawa do 
wychowywania i edukacji dzieci oraz wyposażenia rodziców w narzędzia do obrony przed przymusową indoktrynacją, na przykład ze strony ideologii LGBT. Janusz Korwin-Mikke stwierdził, że »tylko Konfederacja jest w stanie jasno powiedzieć, czego chce większość rodziców a po wejściu do Sejmu będzie chciała wprowadzenia przepisów przeciwko ofensywie środowisk LGBT«" [Polsat News 2019].

Podczas konwencji krajowej Koalicji Obywatelskiej nie odnotowano odniesień do zagadnień światopoglądowych czy roli Kościoła katolickiego w sferze publicznej [Kolenda-Zaleska 2019].

\section{ZAKOŃCZENIE}

Religia stała się ważnym czynnikiem dyskursu politycznego w czasie kampanii parlamentarnej w Polsce w 2019 r. Temat dotyczący roli instytucji Kościoła katolickiego w sferze publicznej był jednak podjęty jedynie przez Prawo i Sprawiedliwość oraz Lewicę. Odnotowano wyrazistą dychotomiczność poglądów tychże komitetów wyborczych. PiS wypowiedział się przeciw idei sekularyzmu, zaś Lewica tę ideę wsparła. Było to dostrzegalne nie tylko w programach tychże ugrupowań politycznych, ale również w wypowiedziach ich przedstawicieli podczas konwencji krajowych. Nieobojętnym dla dyskusji dotyczącej miejsca instytucji Kościoła katolickiego w agendzie politycznej był kontekst przedwyborczy: nagłośnione skandale moralno-obyczajowe hierarchów Kościoła, związki Kościoła katolickiego z politykami PiS w latach 2015-2019, głośne wystąpienie Leszka Jażdżewskiego w Uniwersytecie Warszawskiem oraz marsze równości.

Kwestie ideologiczne związane z religią mogą służyć legitymizacji idei państwa świeckiego bądź służyć obronie wartości chrześcijańskich w sferze publicznej. W dyskusję światopoglądową były zaangażowane podczas kampanii wyborczej jedynie PiS oraz Lewica. W wyborach parlamentarnych w 2015 r. sytuacja była analogiczna do tej z 2019 r. Jak zauważyła Dagmara Głuszek-Szafraniec, dyskusja na temat religii w sferze publicznej była głównie obecna w programach lewicowych partii politycznych. Zdaniem polskiej politolog, stosunkowo rzadko jednak w $2015 \mathrm{r}$. ww. kwestia stawała się najważniejszą w hierarchii poruszanych problemów przez liderów ugrupowań partyjnych [Głuszek-Szafraniec 2017: 278].

Komitety wyborcze Konfederacja i PSL jedynie w ogólny sposób nawiązywały do idei wartości chrześcijańskich, ale jednocześnie nie postulowały marginalizacji i prywatyzacji wszystkiego, co religijne oraz wyłączenia religijności ze sfery publicznej, co można uznać za odrzucenie przez nie idei państwa świeckiego. KW Koalicja Obywatelska pominęła kwestie światopoglądowe w swoim programie wyborczym. Były one również nieobecne w wypowiedziach polityków Platformy w czasie konwencji krajowej.

Otrzymane wyniki analizy potwierdzają dotychczasowe badania politologiczne dotyczące stanowiska polskich partii politycznych wobec religii i Kościoła. Po $1989 \mathrm{r}$. 
partie postkomunistyczne (SdRP, SLD) oraz Unia Pracy konsekwentnie stały na straży neutralności światopoglądowej, opowiadały się za świeckością ceremoniału państwa, za utrzymaniem świeckiego charakteru szkoły publicznej, prawem kobiet do aborcji [Kowalczyk 2015: 157-162]. W tym sensie program KW Lewicy należy postrzegać jako kontynuację stanowiska wyrażonego przez ww. partie polityczne. Podobnie należy postrzegać KW Platformę jako spadkobiercę i kontynuatora stanowiska Unii Wolności w kwestiach światopoglądowych. Ma rację Kowalczyk, kiedy napisał: „Aksjologiczny kompromis i wieloświatopoglądowość stały się jedną z głównych osi programu UW, zawieszonej między liberalizmem a umiarkowanym, posoborowym katolicyzmem" [Kowalczyk 2015: 168].

W kontekście braku wyraźnego stanowiska Platformy Obywatelskiej, dotyczącej idei państwa świeckiego w kampanii wyborczej 2019 r., warto zacytować słowa Donalda Tuska z 2009 r.: „Mam więc wielki dystans do polityków, których nazwałbym konfesyjnymi, którzy chcieliby angażować Kościół do walki politycznej — głównie ze względu na własny interes. Podobny dystans mam do polityków ze środowisk lewicowych, którzy chcą uczynić sztandar wojny z Kościołem, aby cementować w ten sposób swój partyjny elektorat” [Kowalczyk 2015: 169].

Krzysztof Kowalczyk zauważył, że od końca lat 90. XX w. kwestie relacji państwo-Kościół nie były poruszane w założeniach programowych PSL. Przeprowadzona analiza dowodzi brak istotniejszych zmian w linii ideologicznej tej partii [Kowalczyk 2015: 177-179]. Analiza programu Porozumienia Centrum potwierdza, że jego ideologicznym spadkobiercą jest Prawo i Sprawiedliwość [Kowalczyk 2015: 170-177].

Polscy socjologowie - Kaja Kaźmierska oraz Janusz Mariański - zauważyli postępujący proces załamywania się kondycji moralnej społeczeństwa polskiego po 1989 r. Tezę o chrześcijańskim wymiarze moralności Polaków w epoce PRL Mariański nazwał mitem i stereotypem [Mariański 2010: 19-22]. Z kolei Kaźmierska wyeksponowała, jako przyczyny kryzysu moralnego Polaków, „zmiany kulturowe związane nie tyle $\mathrm{z}$ transformacją jako taką, ale z głębokimi przemianami społeczeństwa ponowoczesnego podkreślającego indywidualizm i legitymizującego prawo do indywidualnego wyznaczania granic własnych zachowań" [Boczkowski et al. 2017: 14]. W opinii polskiej socjolog, ,w tej sytuacji oddziaływanie Kościoła staje się dużo, jeśli nie coraz trudniejsze, gdyż przestaje być on traktowany jako punkt odniesienia dla zachowań jednostek a stanowisko Kościoła w kwestiach moralnych i obyczajowych traktowane jest często jako ingerencja w wolność jednostki oraz interpretowane jako element sporu politycznego" [Boczkowski et al.]. Wyniki badań CBOS dowodzą słuszności tez Mariańskiego i Kaźmierskiej. W latach 2011-2018 odnotowuje się stabilizację deklaracji dorosłych Polaków określających ich stosunek do wiary i praktyk religijnych [Boguszewski 2018: 1]. Z kolei po $2005 \mathrm{r}$. poziom zaangażowania Polaków w praktyki religijne dość istotnie się zmniejszył: w latach 2005-2013 odsetek respondentów praktykujących regularnie, przynajmniej raz w tygodniu, z 58\% do 50\%; również w latach 2005-2013 odnotowano więcej 
osób, które w ogóle nie uczestniczą w praktykach religijnych (wzrost z 9\% do 13\%) oraz praktykujących nieregularnie (wzrost z 33\% do 37\%) [Boguszewski 2018: 2]. Zmniejszyła się liczba respondentów wierzących i stosujących się do wskazań Kościoła (w latach 2005-2010 spadek aż o 20\% - z 66\% w 2005 r. do 46\% w 2010 r.) [Boguszewski 2018: 4]. W latach 2015-2018 wzrósł znacząco odsetek negatywnych ocen sytuacji Kościoła katolickiego - w Europie z 32\% do 53\%, w Polsce z 27\% do 37\% [Boguszewski 2018: 5].

Przemilczenie w programach wyborczych trzech dużych ugrupowań politycznych kwestii idei państwa świeckiego można potraktować jako formę uniknięcia bycia stroną w trudnym i niejednoznacznym sporze we współczesnym sposobie postrzegania instytucji Kościoła przez wiernych, którzy jednocześnie partycypują w wyborach powszechnych.

\section{BIBLIOGRAFIA}

Barnat, D. 2017. Sekularyzm polityczny a spór o przekonania sumienia, „Roczniki Filozoficzne”, nr 4, s. 293-323. DOI: https://doi.org/10.18290/rf.2017.65.4-14.

Boguszewski, R. 2018. Religijność Polaków i ocena sytuacji Kościoła katolickiego. Komunikat z badań CBOS, nr 147, https://www.cbos.pl/SPISKOM.POL/2018/K_147_18.PDF (dostęp: 20.04.2020).

Boczkowski, A., Kaźmierska, K., Konecki, K., Matuchniak-Mystkowska, A., Sikora, J. 2017. O roli Akademii, Kościoła katolickiego i języku debaty publicznej, „Władza Sądzenia”, nr 13, s. 9-21.

Casanova, J. 2009. Are we still secular? Exploration on the Secular and the Post-Secular, [w:] Postsecular Society, P. Nynäs, M. Lassander, T. Utriainen (red.), Taylor \& Francis, New BrunswickLondon, s. 27-46.

Fazio, M. 2016. Storia delle idee contemporanee. Una lettura del processo di secolarizzazione, EDUSC, Roma.

Garlicki, J. 2010. Komunikowanie polityczne - od kampanii wyborczej do kampanii permanentnej, „Studia Politologiczne", nr 16, s. 26-45.

Głuszek-Szafraniec, D. 2017. Nauczanie religii $w$ szkole $w$ Polsce - analiza wybranych debat medialnych, „Politeja. Pismo Wydziału Studiów Międzynarodowych i Politycznych Uniwersytetu Jagiellońskiego”, nr 46 (2), s. 65-282. DOI: https://doi.org/10.12.797.Politeja.14.2017.46.11.

Gmitruk, J. 2016. Źródła wiecznego trwania: państwo, Kościót, kultura, wieś, „Niepodległość i Pamięć”, nr 23 (1), s. 39-77.

Hall, A. 2017. Rzeczy (nie)pospolite: Kościót wobec państwa PiS, „Więź”, nr 668 (8), s. 9-93.

KW Konfederacja Wolność i Niepodległość, Polska dla Ciebie. Piątka Konfederacji. Program Konfederacji Wolność i Niepodległość, https://konfederacja.net/wp-content/uploads/2019/09/KONFEDERACJAProgram-Wyborczy-Polska-dla-Ciebie.pdf (dostęp: 20.04.2020).

KW Polskie Stronnictwo Ludowe, Łączymy Polaków. Program wyborczy 2019, https://www.psl.pl/wpcontent/uploads/2019/09/PROGRAM PSL 2019.pdf (dostęp: 20.04.2020).

KW Prawo i Sprawiedliwość, 2019 Program Prawa i Sprawiedliwości. Polski model państwa dobrobytu, http://pis.org.pl/materialy-do-pobrania (dostęp: 20.04.2020).

KW Sojusz Lewicy Demokratycznej, Polska jutra. Główne postulaty lewicy, https://lewica2019.pl/ images/media/Program_Lewicy.pdf (dostęp: 20.04.2020).

Koalicyjny KW Koalicja Obywatelska PO .N IPL Zieloni, Twoja Polska. Program Koalicji Obywatelskiej, https://koalicjaobywatelska.pl/files/Twoja-Polska-Program-Koalicji-Obywatelskiej.pdf (dostęp: 20.04.2020). 
Kolenda-Zaleska, K. 2019. Polacy zostali zmuszeni do życia w państwie należacym do jednego człowieka, https://fakty.tvn24.pl/ogladaj-online,60/wybory-parlamentarne-2019-konwencja-wyborcza-koalicji -obywatelskiej,975168.html (dostęp: 20.04.2020).

Kotulewicz, K. 2014. Koncepcje ustroju politycznego i ekonomiczno-społecznego Polskiego Stronnictwa Ludowego w latach 1989-2011, „Zeszyty Naukowe Uniwersytetu Ekonomicznego w Krakowie”, nr 926.02, s. 21-36. DOI: https://doi.org/10.15678/ZNUEK.2014.0926.0202.

Kowalczyk, K. 2015. Stanowiska polskich partii politycznych wobec religii i Kościoła. Propozycja typologii, „Studia Politicae Universitatis Silesiensis”, nr 15, s. 156-189.

Kubica, E. 2019. „Kler” z rekordem przychodów w polskich kinach, http://boxoffice-bozg.pl/kler-zrekordem-przychodow-w-polskich-kinach/ (dostęp: 20.04.2020).

Leśniczak, R. 2017. Komunikowanie polityczne Konferencji Episkopatu Polski po zakończonych wyborach prezydenckich $2015 \mathrm{r}$. Priming i framing - analiza tygodników opinii „,Newsweek Polska” $i$,Polityka”, „Annales Universitatis Mariae Curie-Skłodowska, Sectio K - Politologia”, nr 24.2, s. 257-277. DOI: https://doi.org/10.17951/k.2017.24.2.257.

Leśniczak, R. 2019. Kategoria negatywizmu a wizerunek prasowy Kościoła katolickiego $w$ kontekście premiery filmu Wojciecha Smarzowskiego „Kler”. Studium medioznawcze polskich tygodników opinii, ,Łódzkie Studia Teologiczne”, nr 28.2, s. 153-172.

Leśniczak, R. 2019. Wizerunek zgromadzeń zakonnych w prasie polskiej (2013-2016), Wydawnictwo Naukowe UKSW, Warszawa.

Leśniczak, R. 2020. Personalizacja wizerunku medialnego instytucjonalnego Kościoła katolickiego w kontekście nadużyć niektórych duchownych wobec nieletnich. Analiza polskich tygodników opinii (2018-2019), „Studia Medioznawcze”, nr 81(2), s. 554-568.

DOI: https://doi.org/10.33077/uw.24511617.ms.2020.2.170.

Mariański, J. 2010. Zmieniająca się przynależność do Kościoła katolickiego w Polsce wyzwaniem dla duszpasterstwa, [w:] Laikat $i$ duchowieństwo w Kościele katolickim w Polsce, J. Baniak (red.), Wydawnictwo Naukowe Wydziału Nauk Społecznych UAM, Poznań, s. 19-46.

Mariański, J. 2017. Sekularyzacja jako megatrend społeczno-kulturowy, „Intercultural Relations”, nr 1.1, s. 231-257. DOI: https://doi.org/10.12797/RM.01.2017.01.12.

Mariański, J. 2018. Kościót katolicki w okresie przemian, „Sociológia a SpoločnoSt”, nr 3.1, s. 19-36.

Mazanka, P. 2014. Refleksje o filozoficznych źródtach sekularyzacji i sekularyzmu, „Studia Nauk Teologicznych", nr 9, s. 55-83.

Niewęgłowski, J. 2004. Rodzina podstawowym środowiskiem wychowawczym. Perspektywa chrześcijańska, „Seminare. Poszukiwania Naukowe”, nr 20, 3, s. 99-410.

Nosowski, Z. 2015. Nowy sojusz oltarza z tronem?, „Więź”, nr 662.58, s. 129-139.

Pacewicz, P. 2019. Koalicja Europejska nie nadąza za elektoratem. Jej wyborcy maja dość ingerencji Kościoła [Sondaże], https://oko.press/koalicja-europejska-nie-nadaza-za-elektoratem-jej-wyborcymaja-dosc-ingerencji-kosciola-sondaze/ (dostęp: 20.04.2020).

Państwowa Komisja Wyborcza. Wybory do Sejmu i Senatu Rzeczypospolitej Polskiej 2019, Wyniki wyborów 2019 do Sejmu RP, https://wybory.gov.pl/sejmsenat2019/pl/wyniki/sejm/pl (dostęp: 20.04.2020).

PAP. 2019. Zandberg: Polska musi zadbać o zwyktych ludzi - taka Polskę zbuduje lewica, https://www. polsatnews.pl/wiadomosc/2019-08-24/kwasniewski-wspolna-lista-lewicy-daje-nadzieje-na-lepszapolske/ (dostęp: 20.04.2020).

PAP, TVN24. 2019. Kaczyński: naszym celem jest budowa polskiej wersji państwa dobrobytu, https:// www.tvn24.pl/wiadomosci-z-kraju,3/jaroslaw-kaczynski-na-konwencji-programowej-w-lubliniewybory-parlamentarne-2019,967602.html (dostęp: 20.04.2020).

PAP, TVN24, Kosiniak-Kamysz: Nie jesteśmy anty-PiS, ani anty-opozycja. Jesteśmy za silna Polska, https://www.tvn24.pl/wiadomosci-z-kraju,3/wybory-parlamentarne-2019-konwencja-psl-koalicjipolskiej,961823.html (dostęp: 20.04.2020).

Polsat News. 2019. Największa w historii obniżka podatkówi , obrona przed LGBT'. Konfederacja przedstawita program, https://www.wprost.pl/wybory-parlamentarne-2019/10252832/najwieksza-w-historiiobnizka-podatkow-i-obrona-przed-lgbt-konfederacja-przedstawila-program.html (dostęp: 20.04.2020). 
Postanowienie Prezydenta Rzeczypospolitej Polskiej z dnia 6 sierpnia 2019 r. w sprawie zarzadzenia wyborów do Sejmu Rzeczypospolitej Polskiej i do Senatu Rzeczypospolitej Polskiej, 6.08.2019, http:// prawo.sejm.gov.pl/isap.nsf/download.xsp/WDU20190001506/O/D20191506.pdf (dostęp: 20.04.2020).

Ribberink, E. 2017. "There is probably no God". A quantitative study of anti-religiosity in Western Europe (doctoral dissertation), KE Leuven, https://www.researchgate.net/profile/Egbert_Ribberink/ publication/321051213_There_is_probably_no_God'_A_quantitative_analysis_of_anti-religiosity_ in_Western_Europe/links/5a0ac74ca6fdcc2736 decc41/There-is-probably-no-God-A-quantitativeanalysis-of-anti-religiosity-in-Western-Europe.pdf (dostęp: 20.04.2020).

Ruffini, F. 1991. La libertà religiosa: storia dell'idea, Feltrinelli Editore, Milano.

Stachurska, A. 2019. Kolejna partia ujawnia ,,jedynki”. Konwencja PSL w Płocku, http://petronews.pl/ kolejna-partia-ujawnia-jedynki-konwencja-psl-w-plocku/ (dostęp: 20.04.2020).

Skórzyński, J. 2019. Atak na Marsz Równości w Białymstoku. Kronika Skórzyńskiego (20-26 lipca 2019), https://oko.press/atak-na-marsz-rownosci-w-bialymstoku-kronika-skorzynskiego-20-26-lipca-2019/ (dostęp: 20.04.2020).

Sztompka, P. 2012. Socjologia. Analiza spoteczeństwa, Wydawnictwo Znak, Kraków.

Szymanek, J.2012.Konstytucjonalizacja rozdziałupaństwai kościoła: uwagiprawnoporównawcze, „Studia Politologiczne", nr 23, s. 23-78.

Tan, S.-H. 2017. Secular Ethics, East and West, [w:] The Oxford Handbook of Secularism, P. Zuckerman, J. Shook (red.), Oxford University Press, Oxford, s. 683.

tokfm.pl. 2019. Pół roku od premiery „Tylko nie mów nikomu”. Sekielski: To dobry czas, by zapytać polityków, co zrobili w tej sprawie, http://www.tokfm.p1/Tokfm/7,103085,25455771, pol-roku-odpremiery-tylko-nie-mow-nikomu-sekielski-to-dobry.html (dostęp: 20.04.2020).

Węgrzecki, J. 2018. Wolność religii w zamyśle autorów Konstytucji RP z 1997 roku, „Horyzonty Polityki”, nr 9.28, s. 29-42.

Zaretti, A. 2003. Religione e modernità in Max Weber: per un'analisi comparata dei sistemi sociali, FrancoAngeli, Milano.

Zuber, M. 2017. Partia Prawo i Sprawiedliwość jako reprezentacja polityczna światopogladu tradycjonalistycznego we wspótczesnej Polsce, „Наукові записки Національного університету Острозька академія", Серія: Культурологія, nr 18, s. 153-160.

Żmuda, R. 1983. Stosunek polskich stronnictw ludowych do Kościoła w latach 1918-1926, „Chrześcijanin w Świecie", nr 15, s. 21-48.

\section{THE IDEA OF SECULARISM IN THE POLISH PARLIAMENTARY CAMPAIGN 2019}

Abstract: The purpose of the article is to assess the degree of presence of the idea of secularism in the election programs of the main political parties participating in the Polish parliamentary elections in 2019. The article adopts the understanding of the so-called political secularism which was referred to the institution of the Roman Catholic Church due to the context of research, as well as the fact that Catholics constitute the dominant part of Polish society and because of the major socio-political importance of the Catholic Church in Poland. The research material were the electoral programs of party election committees, as well as the speeches of their political leaders delivered during the main electoral program conventions. The article increases the cognitive value of the issue of political communication regarding the idea of secularism during the parliamentary campaign of 2019. Research has shown that religion has become an important factor in political discourse during the parliamentary campaign in Poland in 2019. The topic about the role of the Catholic Church institutions in the public sphere was, however, taken up only through Law and Justice and the Left. A clear polarization of views of these election committees was noted. Law and Justice spoke out against the idea of secularism, while the Left supported this idea. The Confederation, Polish People's Party and Civic Coalition remained silent in the election programs about the idea of a secular state.

Keywords: secularism, elections, Catholic Church, politics 


\section{BIOGRAM}

Rafał Leśniczak, dr hab., kierownik Katedry Komunikacji Społecznej, Public Relations i Nowych Mediów Instytutu Edukacji Medialnej i Dziennikarstwa UKSW w Warszawie. Jest autorem ponad 50 publikacji naukowych z zakresu mediów, religii i polityki. Jego zainteresowania naukowe koncentrują się wokół komunikowania politycznego, analizy wizerunku prasowego instytucji, organizacji, liderów politycznych, procesów personalizacji i mediatyzacji, public relations oraz teorii komunikowania masowego. Kontakt e-mail: rafalles@vp.pl. 